DOI: $\square$ https://doi.org/10.15407/techned2020.01.017

\title{
SIMULATION MODEL AND CONTROL ALGORITHM FOR ISOLATED HYDRO-WIND POWER SYSTEM
}

$\quad$ Journal
Publisher
ISSN
Issue
Pages

\author{
Tekhnichna elektrodynamika \\ Institute of Electrodynamics National Academy of Science of Ukraine \\ 1607-7970 (print), 2218-1903 (online) \\ No 1, 2020 (January/February) \\ $17-26$
}

\author{
Authors \\ L.I. Mazurenko ${ }^{1 *}$, K.M. Vasyliv ${ }^{2}$, O.V. Dzhura ${ }^{1 * *}$, A.V. Kotsiuruba ${ }^{3}$ \\ 1. Institute of Electrodynamics of the National Academy of Sciences of Ukraine, \\ pr. Peremohy, 56, Kyiv, 03057, Ukraine, \\ e-mail:mlins@ied.org.ua \\ 2. Lviv Polytechnic National University, \\ S. Bandery, 12, Lviv, 79013, Ukraine \\ 3. Ivan Chernyakhovsky National Defense University of Ukraine, \\ pr. Povitroflotsky, 28, Kyiv, 03049, Ukraine \\ * ORCID ID : https://orcid.org/0000-0002-7059-249X \\ ** ORCID ID : https://orcid.org/0000-0002-0224-3351
}

\section{Abstract}

A new configuration of a three-phase isolated hydro-wind system (IHWS) is considered. The IHWS contains a driven by a regulated hydraulic turbine synchronous generator with electromagnetic excitation, an induction generator with a short circuit rotor driven by an unregulated wind turbine, compensating capacitor bank and regulated dump load fed through an active rectifier. An algorithm for two-level stabilization of the electric frequency in the system is developed. Using the developed simulation model of IHWS, a mathematical simulation of the IHWS electromechanical processes has been performed for a load step and fixed wind speed. The simulation results showed the stable operation of the system in steady-state operating modes and tracking the reference electric frequency levels. References 17, figures 5, table 1. 
Key words: isolated hydro-wind system, synchronous generator, induction generator, active rectifier, dump load, frequency controller.

Received: 25.10.2019

Accepted: 19.12 .2019

Published: 16.01.2020

\section{References}

1. Vasko P.F., Verbovy A.P., Ibrahimova M.R., Pazich S.T. Hydro-storage power plants are the technological basis for the integration of powerful wind and photoelectric power plants into the electric power system of Ukraine. Hydropower of Ukraine. 2017. No 1-2. Pp. 20-25. (Ukr)

2. Sebastian R., Quesada J.. Simulation of an isolated Wind Hydro system. 2nd International Workshop on Simulation for Energy, Sustainable Development and Environment (SESDE 2014), Burdeaus, France, 2014. Pp. 14-19.

3. Goel P. K., Singh B., Murthy S.S. and Kishore N.. Autonomous hybrid system using SCIG for hydro power generation and variable speed PMSG for wind power generation. 2009

International Conference on Power Electronics and Drive Systems

(PEDS), Taipei. 2009. Pp. 55-60. DOI:

https://doi.org/10.1109/PEDS.2009.5385678

4. Aktarujjaman M., Kashem K.A., Negnevitsky M. \& Ledwich G. Dynamics of a hydro-wind hybrid isolated power system. In Australasian Universities Power Engineering Conference (AUPEC 2005). Australia, Tasmania, Hobart, 25 - 28 September 2005. URL:

http://ro.uow.edu.au/cgi/viewcontent.cgi?article=5437\&context=eispapers

(accessed 20.12.19)

5. Xue-Jia Huang, Neng-Sheng Bao. Modeling and simulation analysis of wind-hydro hybrid power plant. 2nd Annual International Conference on Energy, Environmental \& Sustainable Ecosystem Development https://doi.org/10.2991/eesed-16.2017.22

(EESED 2016), Huang, 2016/08. Pp. 169-179. DOI:

6. Mazurenko L.I., Vasyliv K.M.. The law of the electric magnetic processes of the security exercise systems of the autonomous asynchronized generator on the case of the cascade three-phase three-flexible voltage modulator. Tekhnichna Elektrodynamika. 2018. No 6. Pp. 46-49. (Ukr) DOI:

tps://doi.org/10.15407/techned2018.06.046

7. Mazurenko L.I., Dzhura O.V. and Shevchuk S.P. Transients in a transistor-switched capacitor regulator of a stand-alone induction generator supplying a single-phase load. 2017 International Conference on Modern Electrical and Energy Systems

(MEES). Kremenchuk, November 2017. Pp. 244-247. DOI:

https://doi.org/10.1109/MEES.2017.8248901 
8. Sebastián R., Peña-Alzola R. Effective active power control of a high penetration wind diesel system with a Ni-Cd battery energy storage. Renewable Energy. 2010. Vol. 35(5). Pp. 952-965.

DOI: https://doi.org/10.1016/j .renene.2009.11.029

9. Krause P.C., Wasynczuk O. and Sudnoff S.D. Analysis of Electric Machinery and Drive Systems. Piscataway. NJ: Wiley IEEE Press, 2002. 632 p. DOI: https://doi.org/10.1109/978047 0544167

10. Babunski D., Tuneski A. Modelling and design of hydraulic turbine-governor system. 3rd IFAC Workshop on Automatic Systems for Building the Infrastructure in Developing Countries . 2003. Vol. 36. No 7. Pp. 263-267. DOI: https://doi.org/10.1016/S1474-6670(17)35842-1

11. Dierov R.Kh., Glazyrin M.V., Sultonov Sh.M.. Mathematical model Mathematical model of Francis hydroturbine for a hydropower unit of SHPP. Polytechnic Bulletin. Series Engineering Research. Tajik Technical University. 2017. No 2 (38). Pp. 6-13. (Rus)

12. Kuperman $A$. and Rabinovici R. On the speed stability of wind driven induction generators connected to distribution systems. International Journal of Energy and Environment. 2007. Vol. 1. Issue 2. Pp. 57-64.

13. IEEE Recommended Practice for Excitation System Models for Power System Stability Studies.(IEEE Std 421.5-2005, Revision of IEEE Std 421.5-1992). New York. NY:IEEE. 2006. 85 p. URL: https://pdfs.semanticscholar.org/05bc/9ef274285d8be39c5aa0ff9fe0611a6c7874.p $\underline{\mathrm{df}}$ (accessed 20.12.19)

14. Mazurenko L.I., Romanenko V.I., Dzura. O.V. Implementation and experimental study of the induction generator with vector control. Electromechanical and energy saving systems. 2015. No 4/2015(32). Pp. 34-40. (Ukr)

15. Kaura V. and Blasko V. Operation of a phase locked loop system under distorted utility conditions. IEEE Transactions on Industry Applications. Jan.-Feb. 1997. Vol. 33. No 1. Pp. 58-63. DOI:

https://doi.org/10.1109/28.5

$\underline{67077}$

16. Mazurenko L.I., Dzura O.V. Mathematical model and control algorithm of an unregulated wind turbine and IEIG-based izolated energy system. Electromechanical and energy saving systems . 2018. No 3/2018(43). Pp. 24-30. (Ukr)

17. Tamrakar U., Shrestha D., Maharjan M., Bhattarai B., Hansen T., Tonkoski R. Virtual Inertia: Current Trends and Future Directions. Applied Sciences. 2017. Vol. 7(7). No 654. Pp. 1-29. DOI: https://doi.org/10.33 90/app7070654 
Pif. 